\title{
Creating Children's Books to Promote Exposure and Build Communication Skills in Engineering
}

\author{
Lisa Bosman, Purdue University \\ Kelli Chelberg, College of Menominee Nation
}

\begin{abstract}
In an attempt to overcome barriers faced by engineering students, a strengths-based approach to an Introduction to Engineering course was developed and deployed at a minority-serving institution in the US Midwest. This course-based research experience provided an environment that allowed students to learn about various engineering disciplines and improve their communication skills while engaging in a constructivist-grounded process. Students were asked to construct their knowledge and make meaning of the engineering disciplines through the creation of a children's book that introduced young readers to engineering. Although book creation in an engineering course may seem unconventional to many, this course produced students with sound communication skills and a fundamental understanding of engineering that has laid the foundation for their academic careers.
\end{abstract}

Keywords: American Indian, children's books, CURE, Native American, pre-engineering, undergraduate

doi: $10.18833 /$ spur/5/2/1

\section{Identification of the Problem}

The offering of pre-engineering curriculum in the $\mathrm{K}-16$ space has been an increasing trend in an attempt to better prepare students to enroll and persist in bachelor's degree programs in engineering (Poole, DeGrazia, and Sullivan 1999; Lam et al. 2005; Yelamarthi and Mawasha 2008). Pre-engineering coursework is commonly offered in both high school settings and institutions that do not offer a bachelor's degree in engineering). In the latter type of setting, which is the focus of this study, pre-engineering college students will typically complete two years' worth of credits via general education courses and advanced STEM courses in subjects such as calculus, chemistry, computer programming, and physics. Pre-engineering college programs are usually associated with community colleges, liberal arts colleges, and minority-serving institutions as a way for these educational institutions to build capacity both within and between four-year institutions. However, anecdotal evidence has shown that when students complete the two-year pre-engineering curriculum and transfer to a bachelor-degree granting institution to finish their degree, they have limited knowledge and exposure to engineering applications and understanding of the various engineering disciplines.

\section{Current Approaches to the Problem (and Gaps)}

In an attempt to overcome this challenge, institutions that have bachelor's degree programs in engineering typically offer one of three experiences: a pre-college engineering summer program, a first-year engineering experience (FYEE), or a standalone Introduction to Engineering course. First, the pre-college engineering summer programs are commonly one week in duration, provide hands-on problem solving and design related to multiple engineering disciplines, and house the students in dorms, so they get a real taste of college life (Harkins 2016; Elam, Donham, and Soloman 2012; Raines 2012). Unfortunately, these programs target high school students and offer limited applicability to current college students (e.g., community college students or transfer students) navigating the pre-engineering college learning experience. 
Second, some well-established engineering programs will offer their college students what is known as the FirstYear Engineering Experience (FYEE) (Orr et al. 2012; Rumreich and Kecskemety 2019; Aragh and Kajfez 2020). This experience typically crosses over two semesters and requires all engineering students to complete a standard set of coursework before declaring or entering the desired disciplinary major.

Third, if existing resources do not allow for providing the full FYEE, an alternative for many educational institutions is to offer the minimalist approach through a standalone Introduction to Engineering course (Ahmed et al. 2018; Samsuri, Yusof, and Aziz 2017; Roth and Bernhardt 2016). In these cases, the introductory course generally includes a lecture and lab component. The lecture commonly includes presentations by a lead instructor and guest speakers (e.g., faculty representing the various disciplines) with the purpose of introducing students to the various engineering disciplines. The lab commonly provides students with an opportunity to apply the engineering design process using a nonholistic approach that has a narrow focus on improving and reinforcing STEM skills (e.g., technology, math/ science applications, and engineering design). Unfortunately, the Introduction to Engineering course is normally limited to larger and well-established institutions that offer the full engineering bachelor's degrees.

In summary, the pre-college engineering summer program, FYEE, and Introduction to Engineering are typically unavailable to students enrolled in a pre-engineering program (with the intention to transfer to a bachelor's degree-granting institution). The pre-college engineering summer program is limited to high school students; FYEE programs and Introduction to Engineering courses are limited to students enrolled in institutions that offer the full bachelor's degree program. In addition, these experiences are limited, as pre-engineering programs typically do not have the capacity to develop these opportunities due to limited resources (e.g., people, expertise, equipment, space), and many bachelor's degree-granting institutions do not accept the credit for these experiences.

\section{Proposed Solution and Contribution}

This study showcases a strengths-based approach to Introduction to Engineering that leverages student strengths through a nontraditional, course-based undergraduate research experience (CURE) that culminates in a culturally responsive engineering-focused children's book. The CURE was created with funding from the National Science Foundation and was implemented at a small tribal college in the US Midwest, home to a pre-engineering associates degree program and a predominantly American Indian/Native American (AI/NA) student population. Several works detail the book-writing process and extension activities (Bosman, Chelberg, and Fernhaber 2017;
Bosman, Chelberg, and Strimel 2018; Bosman, Chelberg, and Winn 2017).

Although integrating the children's book writing process is not new to higher education (Fernhaber, Albert, and Lupton 2015; Salama et al.2019), this is the first to incorporate the book-writing process into an engineering CURE that seeks to convey information about engineering disciplines and develop research skills of undergraduate students (e.g., critical thinking, oral communication, written communication, information literacy). Moreover, a holistic pedagogical approach was deployed with the intentional application of evidence-based practices in constructivism, storytelling, and cultural relevance. The guiding research question was the following: What are the student benefits to coauthoring engineering-focused children's books as part of a CURE on Introduction to Engineering?

\section{Strengths-Based Approach versus Deficit Approach to Teaching}

The constructivist approach to education has increasingly been recognized as a strengths-based approach in educational circles as an essential tenet of how instruction can be approach and students can be engaged actively in learning. Constructivism refers to the notion that learners construct knowledge for themselves and construct meaning as they learn (Hein 1991). Accepting the constructivist belief requires a pedagogy that provides an opportunity for the learner to engage in meaningful learning based on prior knowledge and experiences. Besides participating in educational activities, instructors create opportunities for the learner to construct knowledge, gain new skills, and increase student engagement (Briede 2013). More specifically, cognitive constructivism is a leading theory in engineering education that emphasizes authentic and realistic learning in which there is "less emphasis . . on directly teaching specific skills and more emphasis on learning in a meaningful context" (Briede 2013, 586).

A deficit approach to learning that has systematically existed across all educational institutions focuses on "things that students cannot do" (Zakaria, Care, and Griffin 2016) in that they "possess motivational and cognitive deficits" (Mejia et al. 2018). More specifically, underrepresented students entering college often lack the necessary preparation to meet higher education's rigor and requirements. In an attempt to understand the challenges faced by students in higher education, those challenges are often framed as deficits as students lack the academic and cultural resources required to be successful. In addition, underrepresented groups may be held responsible for the inequalities that they may face (Davis and Museus 2019), which leads to a deficit-thinking approach because of a heavy focus on students' inadequacies (Smit 2012). This deficit-thinking model creates an environment that alienates students, perpetuates stereotypes, and creates 
barriers to student success (Smit 2012). Deficit approaches or "perspectives prevent many underrepresented students and educators from participating in important learning and teaching activities, which further disadvantage students in fields such as engineering" (Mejia et al. 2018, 158).

\section{American Indian/Native American (AI/NA) Constructive Approach to Teaching}

For many American Indians, storytelling is a traditional pedagogical approach that fulfills several important purposes: communication, entertainment, and education (Hodge et al. 2002). American Indian history is composed of countless histories, stories, and traditions. The many stories told over hundreds of years continue to exist and are passed down from one generation to the next. "Storytelling among the more than three hundred living Indian nations of the United States has not ended. New stories and new storytellers are born every day" (Bruchac 2003, 9) and allow for continued connections of the past, sharing of new experiences, and construction of new knowledge (Bruchac 2003).

Storytelling is an essential and sacred aspect of AI/NA tribal communities and is used to teach cultural beliefs to young children, which is passed down from generation to generation. Hodge and colleagues (2002) suggest that stories provide an opportunity for the storyteller to present both positive and negative situations and their affiliated consequences. Hodge and colleagues $(2002,4)$ also state that, after listening to a story, "the listeners are then invited to interpret the stories through their own experience," allowing for reflection and identification of essential ideas and values. As a result, listeners have the opportunity to construct their own knowledge based on the story, draw their own conclusions, and thus make their own choices.

Ewing (2012) found that AI/NA storytelling and oral tradition were an important component of improving young children's literacy skills. Ewing's findings support the constructivist model that students construct knowledge through interaction due to the cultural practice of storytelling and the oral tradition. These findings may also explain the importance of combining mainstream educational pedagogies with a holistic AI/NA way of knowing.

The use of conventional pedagogies in education with AI/NA students has not improved student retention or success rates (Ewing 2012). There has been significant research conducted on culturally responsive/culturally relevant teaching, yet the research and literature on identifying and recognizing educational pedagogies specific to AI/NA students are limited. Hankes (1996) reviewed studies that detailed the formal and informal instruction of $\mathrm{AI} / \mathrm{NA}$ children by $\mathrm{AI} / \mathrm{NA}$ teachers and compared the attributes of traditional American Indians with constructivist principles. Hankes's literature review suggests that
American Indian "pedagogy and constructivism share common beliefs and perceptions about teaching and learning" (1996, 10). Furthermore, Hankes noted that these pedagogies involve "learner autonomy, which is covertly embedded in indirect, cooperative, sense-making, culturally situated, and time-generous instruction" and that "this conclusion situates the learner not as a dependent but as an autonomous learner" (3). The creation of stories provides a means for AI students to "present essential ideas and values in a simple, entertaining form" (Hodge et al. 2002, 4) while learning critical engineering-specific terminology and skills required for specific engineering disciplines.

\section{Methods}

\section{Study Design}

A total of 10 students participated in the course-based undergraduate research experience Introduction to Engineering. All students were enrolled either part time or full time within the associate degree in the pre-engineering program; thus, students were classified at the first-year or second-year undergraduate equivalency. Eight of the ten were American Indian/Native American (AI/NA), and two were non-AI/NA. The gender breakdown included four females and six males. The CURE was offered during a 16-week semester.

During the first eight weeks, students completed theoretical research to better understand the background of the various engineering disciplines. Students applied their research by working in teams of two during the second eight weeks to write an engineering-focused children's book that was culturally relevant. At the end of the semester, students completed reflections responding to these questions:

- What did you learn about an engineering career and education paths that you didn't know prior to this semester?

- How did your knowledge increase with respect to the engineering disciplines?

- How have your writing skills improved?

- How have your technology skills (e.g., Microsoft Word, PowerPoint, Excel) improved?

- What did you learn about yourself and your abilities?

\section{CURE Theoretical Research}

In the first seven weeks, students conducted research, synthesized findings, and posted responses to an online discussion board. An example of an online discussion prompt is provided in Table 1, and the assessment rubric is provided in Table 2.

In the eighth week, teams were required to pick an engineering discipline (each discipline could only be used once) from the following list: nuclear engineering, industrial engineering, chemical engineering, agricultural 


\section{TABLE 1. Example of an Online Discussion Prompt}

Week 6: Chemical Engineering

Initial Prompt: Chemical engineers apply the principles of chemistry, biology, physics, and math to solve problems that involve the production or use of chemicals, fuel, drugs, food, and many other products. They design processes and equipment for large-scale manufacturing, plan and test production methods and byproducts treatment, and direct facility operations. Chemical engineers work mostly in offices or laboratories. They may spend time at industrial plants, refineries, and other locations, where they monitor or direct operations or solve onsite problems. Nearly all chemical engineers work full time. According to www.bls.gov, the median annual wage for chemical engineers was $\$ 97,360$ in May 2015. Search the internet to find a chemical engineering-focused design you think is especially innovative. Explain the product or service and why you think it is especially innovative.

Response Prompt: Select a peer's post and comment on how it might change in the future.

\section{TABLE 2. Example of the Grading Rubric for Online Discussions}

\begin{tabular}{|l|l|l|}
\hline Initial post & $\begin{array}{l}\text { 6 points: The initial post demonstrates the } \\
\text { student read and understood the initial discus- } \\
\text { sion post expectations. The posting meets the } \\
\text { word count requirement of 150-250 words. } \\
\text { No grammatical errors are identified. }\end{array}$ & $\begin{array}{l}\text { 0-5 points: The initial post did not } \\
\text { completely respond to the assign- } \\
\text { ment instructions, and/or word } \\
\text { count and grammatical expecta- } \\
\text { tions were not met. }\end{array}$ \\
\hline Response post & $\begin{array}{l}\text { 4 points: The response post demonstrates the } \\
\text { student read and understood the response dis- } \\
\text { cussion post expectations. The content is sub- } \\
\text { stantive and moves the conversation forward. }\end{array}$ & $\begin{array}{l}\text { 0-3 points: The response post } \\
\text { did not completely respond to the } \\
\text { assignment instructions and/or did } \\
\text { not completely move the conver- } \\
\text { sation forward. }\end{array}$ \\
\hline
\end{tabular}

engineering, and computer engineering. Once their engineering discipline was selected, students worked in teams to create a research report and presentation based on the topics below:

- Career opportunities in the engineering disciplines

- Famous underrepresented heroes in the engineering disciplines

- Research and design innovations in the engineering disciplines

- Software and technology application(s) used in the engineering disciplines

- Education requirements in the engineering disciplines

These presentations offered student-driven research opportunities into the many different engineering disciplines and were intended to prepare students for the next part of the one-semester class. The research report and research presentation were assessed using a rubric (shown in Table 3 ).

During the first eight weeks, students also received supplementary training from the course instructors and librarians related to (1) finding reputable scholarly articles online; (2) using proper citations and references; (3) creating a research poster; (4) giving effective research presentations;
(5) writing a literature review; and (6) learning Word, PowerPoint, and Excel. Learning about Word, PowerPoint, and Excel helped the students more efficiently and effectively draft aesthetically pleasing research reports and presentations, as well as provided students with sufficient knowledge to format their children's book in preparation for proper publication.

\section{CURE Applied Research}

During the next eight weeks, students used the knowledge acquired from the first half of the semester to co-write a culturally relevant engineering-focused children's book. Students used the Hero's Journey framework (Campbell 2008) to draft a story outline. Then, once the outline was drafted, students worked in the same teams to finalize their story. The students aimed for about 22 pages (2000 words), written with a third- to fifth-grade audience in mind.

The second 8 weeks of the semester was team-taught with three faculty members: an English professor (to advise on the storytelling process), an early education professor (to advise on the book language and associated learning activities), and an engineering professor (to advise on content knowledge). The three faculty also served as editors of the books. At the end of the semester (after grades 
TABLE 3. Example of the Assessment Rubric for Research Report and Research Presentation

\begin{tabular}{|l|l|l|l|}
\hline Focus & $\begin{array}{l}\text { Fully responds to all research } \\
\text { requirements. }\end{array}$ & $\begin{array}{l}\text { Somewhat responds to the research } \\
\text { requirements. }\end{array}$ & $\begin{array}{l}\text { Limited response to research } \\
\text { requirements. }\end{array}$ \\
\hline Content & $\begin{array}{l}\text { Ideas are clear and supported by the } \\
\text { research and class content. }\end{array}$ & $\begin{array}{l}\text { Some ideas are clear and supported by } \\
\text { the research and class content. }\end{array}$ & $\begin{array}{l}\text { Ideas are not clear, and/or ideas are } \\
\text { not supported by the research or class } \\
\text { content. }\end{array}$ \\
\hline Mechanics & $\begin{array}{l}\text { Meets word count (or quantity of minutes } \\
\text { presenting) requirements and limited } \\
\text { errors related to spelling, grammar, and } \\
\text { punctuation (or optimal visual communi- } \\
\text { cation and eye contact). }\end{array}$ & $\begin{array}{l}\text { Does not meet word-count requirements } \\
\text { (or quantity of minutes presenting) and/ } \\
\text { or some errors related to spelling, gram- } \\
\text { mar, and punctuation (or optimal visual } \\
\text { communication and eye contact). }\end{array}$ & $\begin{array}{l}\text { Does not meet word-count requirements } \\
\text { or many errors related to spelling, gram- } \\
\text { mar, and punctuation (or optimal visual } \\
\text { communication and eye contact). }\end{array}$ \\
\hline
\end{tabular}

TABLE 4. Example of the Assessment Rubric for Weekly Children's Book-Writing Sessions

\begin{tabular}{|l|l|}
\hline $100 \%=\mathrm{A}$ & $\begin{array}{l}\text { Submitted a near flawless work by the deadline and positively contributed to } \\
\text { the in-class feedback session }\end{array}$ \\
\hline $90 \%=\mathrm{A} / \mathrm{B}$ & $\begin{array}{l}\text { Submitted flawed work by the deadline and positively contributed to the } \\
\text { in-class feedback session }\end{array}$ \\
\hline $85 \%=\mathrm{B}$ & $\begin{array}{l}\text { Submitted a near flawless work by the deadline and attended but did not par- } \\
\text { ticipate during in-class feedback session }\end{array}$ \\
\hline $80 \%=\mathrm{B} / \mathrm{C}$ & $\begin{array}{l}\text { Submitted a near flawless work by the deadline but did not attend the in-class } \\
\text { feedback session }\end{array}$ \\
\hline $75 \%=\mathrm{C}$ & $\begin{array}{l}\text { Submitted flawed work by the deadline and did not attend the in-class feedback } \\
\text { session }\end{array}$ \\
\hline $70 \%=\mathrm{C} / \mathrm{D}$ & Did not submit work but positively contributed to the in-class feedback session \\
\hline Below 64.9\% $\mathrm{F}$ & Did not submit and did not attend the in-class feedback session \\
\hline
\end{tabular}

were recorded), the instructors continued to work with students to finalize book edits and prepare the books for publication. From a scalability perspective, the CURE children's book-writing project had minimal constraints, as it included the use of free online platforms, including the GIMP graphic design software (illustrations), Kindle Direct Publishing (publishing), and amazon .com (distribution). The weekly children's book writing sessions and student participation were assessed using the rubric below (shown in Table 4).

\section{Results}

\section{Artifact Development}

The funded CURE has resulted in a total of eight books with the following engineering disciplines: industrial, mechanical, electrical, computer, nuclear, environmental, civil, and biomedical. An example is provided in Figure 1.

\section{Student Feedback}

In response to the first reflection question (What did you learn about an engineering career and education paths that you didn't know prior to this semester?), the course-based applied research experience allowed students to learn about the different engineering disciplines. One student stated:

This semester I learned that there are multiple career paths for engineers, depending on what the person might want to do with their skills. Personally, I learned that I should investigate civil engineering with an emphasis on environmental engineering. Previously, I did not really know what an engineer was, or what one might do. I learned about different disciplines that an engineer can specialize in.

Similarly, another student said, "I kind of had an idea of what each [engineering discipline] was but did not know how they applied to real life. Being able to do the research on designs and innovations has shown me the different things that each career does. I thought it was better to see it this way because that could be my potential future career."

In response to the second reflection question (How did your knowledge increase with respect to the engineering 
FIGURE 1. A Children's Book Focused on Engineering That Was Developed by Faculty as an Example for Students (front and back covers)

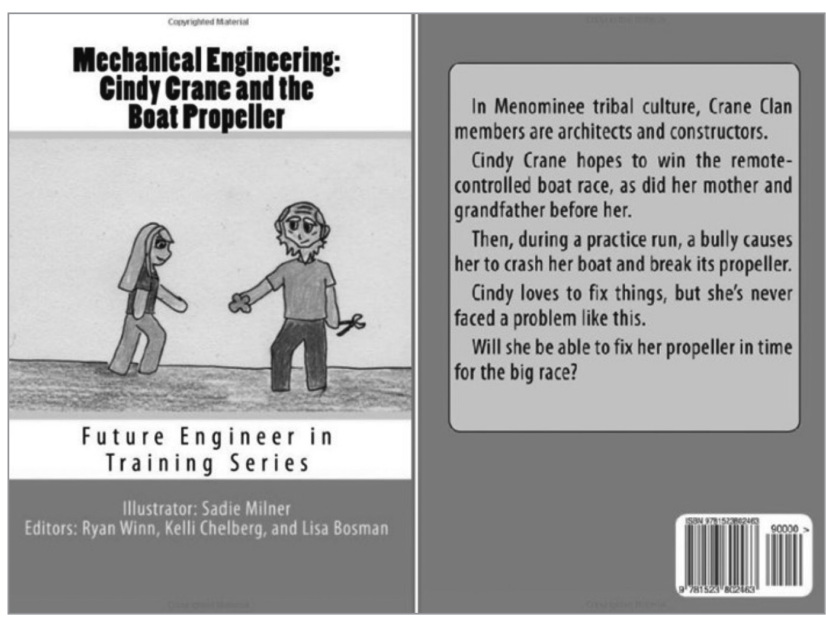

Note: Editors Ryan Winn, Kelli Chelberg, and Lisa Bosman; illustrator Sadie Milner.

disciplines?), the course-based applied research experience allowed students to recognize knowledge gains with respect to what engineers actually do and how it impacts everyday tasks. One student stated, "It was cool learning about how much engineering is actually involved in everyday life. Almost everything that takes place in today's world is part of engineering I always enjoyed how stuff works and how it's put together. I have a better understanding about the role engineers play." Another student reported, "Industrial engineering was the most surprising engineering field I learned about. I think it is really interesting how they actually work by watching workers perform tasks, investigate equipment set up and look into the delivery process to determine whether or not any changes can be made to improve the efficiency of the whole process."

In response to the third reflection question (How have your writing skills improved?), the course-based applied research experience allowed students to acknowledge skill gains in accepting constructive feedback and staying on topic. One student reflected, "I am not sure whether or not my writing skills have improved. What I can say is that I have learned that I often mistake critique for criticism, and I was able to change my attitude so that I could be more productive. I also learned that I am able to have an idea, run with it, scrap it and start all over. That type of challenge was more exciting than overwhelming for me." Another student asserted, "I hate writing and don't think I'll ever like it. I'm a numbers person! But I guess I learned how to stay on topic and not ramble."

In response to the fourth reflection question (How have your technology skills [e.g. Microsoft Word, PowerPoint,
Excel] improved?), the course-based applied research experience allowed students to acquire new technology skills applicable to experiences both inside and outside this class (such as in other classes and jobs). One student acknowledged, "My technology skills have improved majorly! I now know how to do all of the cool stuff in each of the programs. For our final project in project management we had to make a report. I was able to do all of the smart art stuff on [W] ord to make our network diagrams. I also was able to edit and cut our videos together into one video in PowerPoint." Another student stated, "My technology skills have become more efficient and fluid. I'm glad that I was able to learn the different short cuts within each program, such as commands, drags, which have helped me in all my classes, and jobs."

In response to the fifth reflection question (What did you learn about yourself and your abilities?), the course-based applied research experience allowed students to discover things about themselves with respect to their fit with engineering and/or doing research. One student stated, "What I learned about myself is that engineering might not actually be for me, but I am willing to continue on my journey of discovery." Another student reported, "I've learned that I am a better writer than I initially thought, I think I may continue writing in my free time."

\section{Conclusion}

Students gained many benefits by participating in the CURE on Introduction to Engineering that produced children's books. First, they gained exposure to and achieved a greater understanding concerning the various engineering disciplines. This helped students to determine the discipline they will select once they enter a bachelor's program in engineering. In one case, one student learned that engineering was not a good fit. Second, students obtained skill improvements in their written communication and technology-specifically, the Microsoft applications of Word, PowerPoint, and Excel. Third, instructors observed that there was an increase in student confidence and student empowerment when the official publication process was complete.

For instructors interested in implementing a similar children's book-writing approach within their research programs or classrooms, it is recommended that they use a collaborative approach - either with a team of instructors from various backgrounds or with a team of students from various backgrounds (Fernhaber et al. 2015). Although this study highlights an example of children's book development in the engineering CURE classroom, the authors are confident that the same approach to book writing could be applied within any disciplinary environment. Thus, at other institutions, it is recommended that faculty developers consider integrating CURE-based children's 
book writing in disciplines such as natural sciences, social sciences, and humanities.

\section{References}

Ahmed, Syed Musthak, G. Madhuri, M. Sampath Reddy, and Sridhar S. Condoor. 2018. "Skill Development in Freshmen by Adopting Project Based Learning: 'Introduction to Engineering' Course." Journal of Engineering Education Transformations (spec. issue): n.p.

Aragh, M. Jean Mohammadi, and Rachel L. Kajfez. 2020. "Ten Years of First-Year Engineering Literature (2005-2014): A Systematic Literature Review of Four Engineering Education Journals." International Journal of Engineering Education 36(1): 18-39.

Bosman, Lisa, Kelli Chelberg, and Stephanie Fernhaber. 2017. "Introduction to Engineering: A Constructivist-Based Approach to Encourage Engagement and Promote Accessibility." Global Journal of Engineering Education 19: 237-242.

Bosman, Lisa, Kelli L. Chelberg, and Greg Strimel. 2018. "Incorporating Engineering and Renewable Technologies into the K-5 Classroom through Culturally Relevant Literature and Design Challenges." The Elementary STEM Journal 23(2): 27-29.

Bosman, Lisa, Kelli Chelberg, and Ryan Winn. 2017. "How Does Service Learning Increase and Sustain Interest in Engineering Education for Underrepresented Pre-Engineering College Students?" Journal of STEM Education: Innovations and Research 18(2): 1-9.

Briede, Baiba. 2013. "A Constructivist Approach in Engineering Education.” Engineering for Rural Development 12: 584-589.

Bruchac, Joseph. 2003. Our Stories Remember: American Indian History, Culture, and Values through Storytelling. Vol. 1. Golden, CO: Fulcrum Publishing.

Campbell, Joseph. 2008. The Hero with a Thousand Faces. Bollingen series, vol. 17. San Francisco: New World Library.

Davis, Lori Patton, and Samuel D. Museus. 2019. "What Is Deficit Thinking? An Analysis of Conceptualizations of Deficit Thinking and Implications for Scholarly Research." NCID Currents 1(1): 1-14. doi: 10.3998/currents.17387731.0001.110

Elam, Matthew, Brent Donham, and Stephanie R. Soloman. 2012. "An Engineering Summer Camp for Underrepresented Students from Rural School Districts." Journal of STEM Education: Innovations and Research 13(2): 1-10.

Ewing, Rebecca Jane. 2012. "Native American Storytelling: Oral Tradition as a Cultural Component of Learning." PhD diss., Walden University.

Fernhaber, Stephanie A., Erin Albert, and Angela Lupton. 2015. "Publishing Children's Books with Interdisciplinary Teams: Reflecting on Student Innovation through the Lens of Tony Wagner." Journal of Entrepreneurship Education 18(2): 59-72.

Hankes, Judith Elaine. 1996. "Investigating the Correspondence between Native American Pedagogy and Constructivist Based Instruction." Paper presented at the Annual Convention of the American Educational Research Association, New York, NY. Accessed August 26, 2021. https://files.eric.ed.gov/fulltext/ ED401086.pdf
Hurricanes, Meg. 2016. "Engineering Boot Camp: A Broadly Based Online Summer Bridge Program for Engineering Freshmen." Paper presented at the 2016 American Society for Engineering Education Annual Conference \& Exposition, New Orleans, Louisiana. doi: 10.18260/p.26623

Hein, George E. 1991. "Constructivist Learning Theory." Institute for Inquiry. Accessed August 31, 2021. http://www.exploratorium.edu/ifi/resources/constructivistlearning.html

Hodge, Felicia Schanche, Anna Pasqua, Carol A. Marquez, and Betty Geishirt-Cantrell. 2002. "Utilizing Traditional Storytelling to Promote Wellness in American Indian Communities." Journal of Transcultural Nursing 13(1): 6-11. doi: $10.1177 / 104365960201300102$

Lam, Paul C., Tirumalai Srivatsan, Dennis Doverspike, John Vesalo, and P. Ruby Mawasha. 2005. "A Description and Evaluation of the Effects of a Pre-Engineering Program for Underrepresented, Low-Income, and/or First Generation College Students at the University of Akron." Journal of STEM Education: Innovations and Research 6(3): 14-20. doi: 10.1615/jwomenminorscieneng. v6.i3.30

Mejia, Joel Alejandro, Renata A. Revelo, Idalis Villanueva, and Janice Mejia. 2018. "Critical Theoretical Frameworks in Engineering Education: An Anti-Deficit and Liberative Approach." Education Sciences 8: 158-171. doi: 10.3390/educsci8040158

Orr, Marisa K., Catherine E. Brawner, Susan M. Lord, Matthew W. Ohland, Richard A. Layton, and Russell A. Long. 2012. "Engineering Matriculation Paths: Outcomes of Direct Matriculation, First-Year Engineering, and Post-General Education Models." In 2012 Frontiers in Education Conference Proceedings, 1-5. doi: 10.1109/FIE.2012.6462357

Poole, Susan J., Janet L. DeGrazia, and Jacquelyn F. Sullivan. 1999. "Assessing K-12 Pre-Engineering Outreach Programs." In FIE'99 Frontiers in Education. 29th Annual Frontiers in Education Conference. Designing the Future of Science and Engineering Education. Conference Proceedings, 11B5-15. doi: 10.1109/FIE.1999.839234

Raines, Joan M. 2012. "FirstSTEP: A Preliminary Review of the Effects of a Summer Bridge Program on Pre-College STEM Majors." Journal of STEM Education: Innovations and Research 13(1): 1-8.

Roth, Mary, and Kristen L. Sanford Bernhardt. 2016. "Using Concept Maps for Assessment and Improvement of a MultiSection Introduction to Engineering Course." Paper presented at the 2016 American Society for Engineering Education Annual Conference \& Exposition, New Orleans, Louisiana. doi: $10.18260 /$ p. 27139

Rumreich, Laine E., and Krista M. Kecskemety. 2019. "FirstYear Engineering Student Perceptions and Use of iPad Technologies: A Quantitative Investigation of Mobile Learning." In 2019 IEEE Frontiers in Education Conference (FIE), 1-5. doi: 10.1109/FIE43999.2019.9028411

Salama, Ghada, Tala Katbeh, Brady Creel, G. Benjamin Cieslinski, Mohamed Gharib, Farah Ramadan, and Weam Mazen. 2019. "Illustrating Engineering Education: A Children's Book to Support STEM Outreach in Qatar." In 2019 IEEE International 
Conference on Engineering, Technology and Education (TALE), 1-5. doi: 10.1109/tale48000.2019.9225947

Samsuri, Nur Shahira, Khairiyah Mohd Yusof, and Azmahani Abdul Aziz. 2017. "Preparing First Year Engineering Students to Become Engineers: The Impact of an 'Introduction to Engineering' Course." Journal of Technical Education and Training 9(1): 1-16.

Smit, Reneé. 2012. "Towards a Clearer Understanding of Student Disadvantage in Higher Education: Problematising Deficit Thinking." Higher Education Research \& Development 31: 369-380. doi: 10.1080/07294360.2011.634383

Yelamarthi, Kumar, and P. Ruby Mawasha. 2008. "A Pre-Engineering Program for the Under-Represented, Low-Income and/or First Generation College Students to Pursue Higher Education." Journal of STEM Education 9(3): 5-15.

Zakaria, Zuraimi, Esther Care, and Patrick Griffin. 2016. "Scaffolding Instruction Where It Matters: Teachers' Shift from Deficit Approach to Developmental Model of Learning." Journal of Education and Practice 7(23): 144-152.

\section{Lisa Bosman}

Purdue University, lbosman@purdue.edu

Lisa Bosman, is an assistant professor in the Purdue Polytechnic Institute, Purdue University. Her engineering education research interests include the entrepreneurial mindset, energy education, interdisciplinary education, and faculty professional development. Her desire to increase STEM education accessibility and attainment has resulted in her founding of the Purdue University iAGREE Labs. She has authored more than 50 publications in international and national journals and conferences.

Kelli Chelberg is an associate professor at the College of Menominee Nation. Her research interests include mentoring and identifying educational strategies as it relates to students of color and their persistence in postsecondary educational settings and identifying culturally responsive educational practices for preservice teachers. 